\title{
PENGARUH KECERDASAN EMOSIONAL, IKLIM KERJA DAN KOMPETENSI TERHADAP KINERJA GURU DI SMA NEGERI 6 BINJAI KECAMATAN BINJAI UTARA
}

\author{
Evi Aryanti \\ Universitas Islam Sumatera Utara \\ evi.aryanti@gmail.com
}

\begin{abstract}
The formulation of the problem in this study is How the influence of Emotional Intelligence, Work Climate and Competence on Teacher Performance in SMA Negeri 6 Binjai, North Binjai District, both partially and simultaneously. The population and sample of this study were all teachers in the school, amounting to 64 people. The sampling technique uses total sampling. Data collection techniques used were direct interviews and questionnaires. The results of this study are partially the Emotional Intelligence variable has a positive and significant effect on Teacher Performance with tcount $>$ ttable, (2.633> 2.00,), Work Climate variable has a positive and significant effect on Teacher Performance with tcount $>$ ttable, $(2,812>2.00)$ and Competency Variables have a positive and significant effect on Teacher Performance with tcount> ttable, (2.701> 2.00). Simultaneously the variables of Emotional Intelligence, Work Climate and Competence have a positive and significant effect on Teacher Performance with Fcount> Ftable, (11,492> 2.75). R2 (RSquare) value of 0.625, which means that the variable Emotional Intelligence, Work Climate and Competence has a positive and significant effect on Teacher Performance in SMA Negeri 6 Binjai, North Binjai district, 62.50\%, and the remaining $37.50 \%$, influenced by other factors not examined.
\end{abstract}

Keywords: Emotional Intelligence, Work Climate, Teacher Competence and Performance

ABSTRAK : Rumusan masalah dalam penelitian ini adalah Bagaimana pengaruh Kecerdasan Emosional, Iklim Kerja dan Kompetensi Terhadap Kinerja Guru di SMA Negeri 6 Binjai Kecamatan Binjai Utara baik secara parsial maupun simultan. Populasi dan sampel penelitian ini adalah seluruh guru di sekolah tersebut yang berjumlah 64 orang. Teknik pengambilan sampel menggunakan total sampling. Teknik pengumpulan data yang digunakan adalah wawancara langsung dan angket. Hasil penelitian ini adalah secara parsial variabel Kecerdasan Emosional berpengaruh Positif dan signifikan terhadap Kinerja Guru dengan nilai $t_{\text {hitung }}>t_{\text {tabel, }}(2,633>2,00$, , ), variabel Iklim Kerja berpengaruh Positif dan signifikan terhadap Kinerja Guru dengan nilai $t_{\text {hitung }}>t_{\text {tabel, }}(2,812>2,00)$ dan Variabel Kompetensi berpengaruh positif dan signifikan terhadap Kinerja Guru dengan nilai $t_{\text {hitung }}>t_{\text {tabel, }}(2,701>2,00)$. Secara Simultan variabel Kecerdasan Emosional, Iklim Kerja dan Kompetensi berpengaruh positif dan signifikan terhadap Kinerja Guru dengan nilai $F_{\text {hitung }}>F_{\text {tabel, }}$ (11,492 > 2,75). Nilai $R^{2}$ (RSquare) sebesar 0.625, yang berarti bahwa variabel Kecerdasan Emosional, Iklim Kerja dan Kompetensi berpengaruh Positif dan signifikan terhadap Kinerja Guru di SMA Negeri 6 Binjai Kecamatan Binjai Utara sebesar 62,50\%, dan sisanya sebesar 37,50\% lagi, dipengaruhi oleh faktor-faktor lain yang tidak diteliti.

Kata Kunci : Kecerdasan Emosional, Iklim Kerja, Kompetensi dan Kinerja Guru

\section{Pendahuluan}

Mengajar merupakan suatu usaha guru dalam mengelola perhatian dan waktu siswa yang dimulai dari awal sampai akhir di dalam kelas. Mengajar adalah usaha guru dalam menciptakan kondisi-kondisi atau mengatur lingkungan sedemikian rupa, sehingga terjadi interaksi antara siswa dengan lingkungan, termasuk guru dan media pengajaran. Peranan guru dalam mengelola proses belajar mengajar, antara lain sebagai fasilitator, yang berusaha menciptakan kondisi belajar mengajar yang efektif, sehingga memungkinkan berlangsungnya proses pembelajaran, mengembangkan bahan belajar dengan baik, dan meningkatkan kemampuan 
siswa dalam belajar, agar tujuan belajar dapat dicapai.

Kinerja seorang guru adalah salah satu hal yang penting dalam setiap organisasi sekolah, karena kinerja merupakan hasil kerja yang dilakukan setiap guru untuk memperoleh hasil yang optimal. Dengan kinerja yang tinggi maka tujuan organisasi sekolah akan mudah tercapai. Kinerja pada dasarnya merupakan sesuatu yang bersifat individual. Setiap individu memiliki kinerja yang berbeda-beda sesuai dengan sistem nilai yang berlaku pada dirinya.

Berbicara soal kinerja guru yang bahwasanya memang dipengaruhi oleh faktor psikologis yaitu kecerdasan emosional. Dimana kecerdasan emosional dapat membawa keberhasilan pada sebuah kinerja seorang guru pada khususnya, karena kecerdasan emosional yang baik melahirkan pemikiran, perasaan, perilaku, dan tujuan pengelola dengan sikap (1) disiplin diri, jujur dan tulus kepada diri sendiri, membangun kekuatan pribadi, termasuk kesadaran diri, mendengarkan suara hati, hormat, tanggungjawab dan koneksi, (2) memantapkan diri dan maju terus, membangun inspirasi diri sendiri dan orang lain, termasuk keaslian, keuletan, dan hubungan saling percaya, (3) membangun watak dan kewibawaan, mengembangkan potensi, integritas, dan tujuan hidup, dan (4) merasakan peluang dan menciptakan masa depan, membangun titik temu, inovasi, intuitif, transformasi, situasional, dan kecerdasan yang luwes.

Kecerdasan emosional merupakan suatu bagian dari daya manusia yang mulai diyakini dengan menggunakan istilah EQ. Emosi dan pikiran adalah dua bagian dari suatu keseluruhan. Itulah sebabnya, istilah yang baru-baru ini diciptakan untuk menggambarkan kecerdasan hati adalah EQ. (Segal, 2000:5, dialihbahasakan oleh Ary Nilandari). Dalam perkembangan hidup manusia suatu kecerdasan emosi memiliki kontribusi yang sangat besar dalam kehidupan dibandingkan dengan kecerdasan yang lainnya. Kecerdasan intelektual yang selama ini kita anggap sebagai tolak ukur keberhasilan seseorang ternyata memiliki peranan hanya sebesar 20 persen, dan 80 persen dipengaruhi oleh kecerdasan yang lainnya, dimana 45 persen diantaranya dipengaruhi oleh kecerdasan emosi. Angka tersebut menunjukkan peranan kecerdasan emosi memiliki tingkat keterhubungan yang sangat besar dengan keberhasilan seseorang. Seperti yang diungkapkan oleh Ary Ginanjar Agustian (2001:17):
Seorang guru dalam melaksanakan tugas dan perannya di dalam kelas, maupun tugas kependidikannya di luar kelas sangat mempengaruhi berbagai faktor, baik faktor internal maupun faktor eksternal. Faktor internal yang mepengaruhi kinerja guru adalah kompetensi yang dimilikinya sebagai seorang guru sedangkan faktor eksternal adalah iklim kerja yang tercipta didalam organisasi atau lembaga dimana dia bekerja. Kinerja yang dimiliki guru akan bermakna apabila diseimbangkan dengan sebuah niat yang tulus, dan selalu menyadari akan kekurangannya, dan berupaya untuk memperbaiki kekurangan tersebut sebagai upaya untuk meningkatkan ke arah yang lebih positif.

\subsection{Rumusan Masalah}

Rumusan masalah dalam penelitian ini sebagai berikut : Bagaimana pengaruh Kecerdasan Emosional, Iklim Kerja dan Kompetensi terhadap Kinerja Guru di SMAN 6 Binjai Kecamatan Binjai Utara.

\subsection{Batasan Masalah}

Dari hasil identifikasi masalah tersebut, maka penulis membatasi penelitian ini hanya pada Kecerdasan Emosional, Iklim Kerja dan Kompetensi terhadap Kinerja Guru di SMAN 6 Binjai Kecamatan Binjai Utara.

\subsection{Hipotesis}

Hipotesis dalam penelitian ini adalah melihat pengaruh variabel Kecerdasan Emosional, Iklim Kerja, Kompetensi dan Kinerja Guru di SMAN 6 Binjai Kecamatan Binjai Utara.

\subsection{Tujuan Penelitian}

Penelitian ini bertujuan untuk mengetahui :

a. Pengaruh Kecerdasan Emosional terhadap Kinerja Guru di SMAN 6 Binjai Kecamatan Binjai Utara.

b. Pengaruh Iklim Kerja terhadap Kinerja Guru di SMAN 6 Binjai Kecamatan Binjai Utara.

c. Pengaruh Kompetensi terhadap Kinerja Guru di SMAN 6 Binjai Kecamatan Binjai Utara.

d. Pengaruh Kecerdasan Emosional, Iklim Kerja dan Kompetensi terhadap Kinerja Guru di SMAN 6 Binjai Kecamatan Binjai Utara.

\section{Metode Penelitian}

\subsection{Populasi dan Sampel}

Populasi dalam penelitian ini adalah seluruh guru-guru PNS di SMAN 6 Binjai Kecamatan Binjai Utara yang berjumlah 64 orang. 
Menurut Arikunto (2006:134), sampel adalah bagian dari populasi yang mempunyai peluang/estimasi yang sama untuk menjadi sampel. Apabila subjeknya kurang dari 100, lebih baik diambil seluruhnya sehingga penelitiannya merupakan penelitian populasi. Tetapi jika jumlah subjeknya lebih besar dari 100, maka dapat diambil sampel antara $10-15 \%$ atau 20$24 \%$ atau lebih. Dengan demikian merujuk dari pernyataan diatas maka sampel dalam penelitian ini seluruh populasi yang berjumlah 64 orang guru.

\subsection{Uji Normalitas Data}

Uji normalitas data bertujuan untuk mengetahui apakah data yang digunakan dalam model regresi telah terdistribusi normal atau tidak. Alat uji yang digunakan dalam penelitian ini adalah uji Kolmogrov - Smirnov test. Data dinyatakan normal apabila nilai Kolmogorov Smirnov Z lebih kecil dari $1,97(\mathrm{Z}<1,97)$ dengan level asymp.sig (2 tailed) $>$ Level signifikan $\mathrm{t}$ $(5 \%)$.

Tabel 1. Uji Kolmogorov Smirnov

One-Sample Kolmogorov-Smirnov Test

\begin{tabular}{|c|c|c|c|c|c|}
\hline & & $\mathrm{X} 1$ & $\mathrm{X} 2$ & X3 & Y \\
\hline \multicolumn{2}{|l|}{$\mathrm{N}$} & 64 & 64 & 64 & 64 \\
\hline \multirow{2}{*}{ Normal Parameters ${ }^{\mathrm{a}, \mathrm{b}}$} & Mean & $\begin{array}{r}63.342 \\
7\end{array}$ & 63.0135 & 63.1901 & 63.0452 \\
\hline & $\begin{array}{l}\text { Std. } \\
\text { Deviation }\end{array}$ & $\begin{array}{r}0.1365 \\
4\end{array}$ & 0.17356 & 0.14290 & 0.17203 \\
\hline \multirow{3}{*}{$\begin{array}{l}\text { Most Extreme } \\
\text { Differences }\end{array}$} & Absolute & .177 & .168 & .190 & 0.565 \\
\hline & Positive & .171 & .191 & .090 & .081 \\
\hline & Negative & -.041 & -.057 & -.038 & -030 \\
\hline \multirow{2}{*}{\multicolumn{2}{|c|}{$\begin{array}{l}\text { Kolmogorov-Smirnov Z } \\
\text { Asymp. Sig. (2-tailed) }\end{array}$}} & 1.251 & 1.278 & 1.491 & .628 \\
\hline & & .177 & .182 & .191 & 187 \\
\hline
\end{tabular}

Dari tabel 1, diatas dapat dilakukan uji :

Kolmogorov - Smirnov Z $<1,97$

$$
\begin{aligned}
& \mathrm{X} 1=1,251<1,97 \\
& \mathrm{X} 2=1,278<1,97 \\
& \mathrm{X} 3=1,491<1,97 \\
& \mathrm{Y}=0,628<1,97
\end{aligned}
$$

Asymp Sig (2Tailed) $>$ Level Sig. 5\% $(0,05)$

$$
\begin{aligned}
& \mathrm{X} 1=0,177>0,05 \\
& \mathrm{X} 2=0,182>0,05 \\
& \mathrm{X} 3=0,191>0.05 \\
& \mathrm{Y}=0,187>0,05
\end{aligned}
$$

Melihat hasil pengolahan data dengan bantuan program SPSS diatas maka dapat disimpulkan bahwa seluruh data dalam penelitian ini berdistribusi dengan normal.

\subsection{Uji Multikolinearitas}

Model regresi berganda harus terbebas dari multikolinearitas untuk setiap variabel independentnya. Identifikasi keberadaan multikolinearitas ini dapat didasarkan pada beberapa kriteria, yaitu: Nilai tolerance dan variance inflation faktor (VIF), dimana nilai VIF tidak lebih dari 10 dan nilai tolerance tidak kurang dari 0,1 .

Tabel 2. Uji Multikolinieritas Coefficients $^{\mathrm{a}}$

\begin{tabular}{|c|r|r|}
\hline \multirow{2}{*}{ Model } & \multicolumn{2}{|c|}{ Collinearity Statistics } \\
\cline { 2 - 4 } & Tolerance & \multicolumn{1}{c|}{ VIF } \\
\hline X1 & .712 & 7.476 \\
1 & .618 & 6.598 \\
X2 & .633 & 6.825 \\
\hline \multicolumn{2}{|c}{ X3 } \\
\multicolumn{2}{|c}{ a. Dependent Variable: $Y$}
\end{tabular}

Hasil perhitungan pada Tabel 2, nilai tolerance memperlihatkan bahwa masing-masing variabel independent tidak ada yang memiliki nilai yang kurang dari 0,1 dan nilai VIF tidak lebih dari 10 yang berarti syarat ini terpenuhi.

\subsection{Uji Heteroskedastisitas}

Suatu model regresi linear berganda dapat dikatakan bebas dari permasalahan heterokedastisitas menurut Gujarati (2006: 143) adalah :

a. Titik-titik menyebar di atas dan di bawah atau di sekitar angka 0 (nol). 
b. Titik-titik data tidak mengumpul hanya di atas atau di bawah saja

c. Penyebaran titik-titik data tidak boleh membentuk pola bergelombang, melabar kemudian menyempit dan melebar kembali

d. Penyebaran titik-titik data sebaiknya tidak berpola

e. Dikatakan bebas dari heterokedastisitas jika nilai $\mathrm{p}$ value atau signifikansi $>0,05$

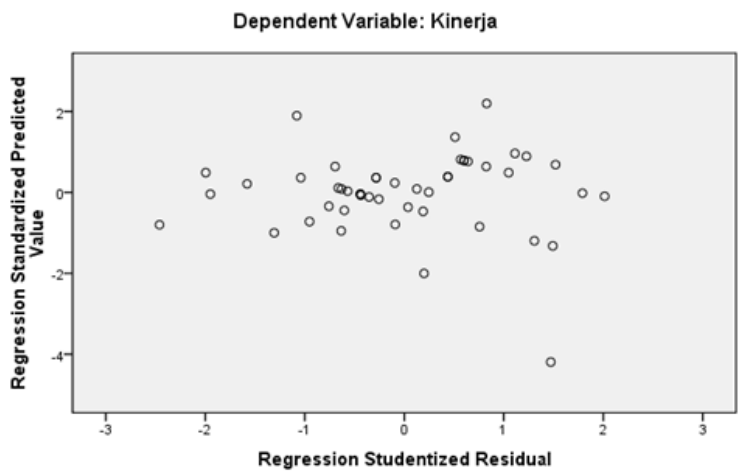

Gambarl Grafik scatterplot Uji Heteroskedastisitas

\section{Hasil dan Pembahasan \\ 3.1. Analisis Regresi Linier Berganda}

Kerangka hubungan antara ( $\mathrm{X}_{1}, \mathrm{X}_{2}, \mathrm{X}_{3}$ terhadap Y) dapat dibuat mealalui persamaan variabel sebagai berikut :

$$
\mathbf{Y}=\mathbf{a}+\mathbf{b}_{1} \mathbf{X}_{1}+\mathbf{b}_{2} \mathbf{X}_{2}+\mathbf{b}_{3} \mathbf{X}_{3}+e
$$

Untuk mengetahui koefisien jalur dapat dilihat dari nilai Beta pada table Coefficienst berikut :

Coefficients $^{\mathrm{a}}$

Tabel 3. Regresi Linear Berganda

\begin{tabular}{|l|r|r|r|r|r|}
\hline \multirow{2}{*}{ Model } & \multicolumn{2}{|c|}{$\begin{array}{c}\text { Unstandardized } \\
\text { Coefficients }\end{array}$} & $\begin{array}{c}\text { Standardized } \\
\text { Coefficients }\end{array}$ & \multirow{2}{*}{ Sig. } & \\
\cline { 2 - 4 } & \multicolumn{1}{|c|}{$\mathrm{B}$} & \multicolumn{1}{c|}{ Std. Error } & \multicolumn{1}{c|}{ Beta } & & \\
\hline (Constant) & 8.772 & 0.525 & & 7.425 & .000 \\
1 & .581 & .103 & .282 & 2.632 & .000 \\
Kec.Emosional & .542 & .224 & .362 & 2.812 & .001 \\
Iklim Kerja & .567 & .210 & .371 & 2.701 & .001 \\
\hline
\end{tabular}

a. Dependent Variable: Kinerja Guru

Dari tabel berikut diketahui masing-masing koefisien dari tiap variabel, dan didapatan persamaan sebagai berikut :

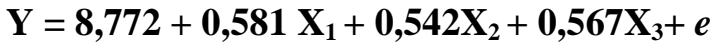

a. Nilai konstanta sebesar 8,772 menyatakan bahwa jika Kecerdasan Emosional, Iklim Kerja dan Kompetensi diabaikan maka nilai Kinerja Guru di SMA Negeri 6 Binjai Kecamatan Binjai Utara sebesar 8,772 (asumsi faktor lain konstan).

b. Koefisien $\mathrm{X}_{1}$ sebesar 0,581 menyatakan bahwa Kecerdasan Emosional berpengaruh sebesar 0,581 atau sebesar 58,10\% terhadap Kinerja Guru di SMA Negeri 6 Binjai Kecamatan Binjai Utara (asumsi faktor lain konstan).

c. Koefisien $\mathrm{X}_{2}$ sebesar 0,542 menyatakan bahwa Iklim Kerja berpengaruh sebesar 0,542 atau sebesar 54,20 \% terhadap Kinerja Guru di SMA Negeri 6 Binjai Kecamatan Binjai Utara (asumsi faktor lain konstan).

d. Koefisien $\mathrm{X}_{3}$ sebesar 0,567 menyatakan bahwa Kompetensi berpengaruh sebesar 0,567 atau sebesar 56,70 \% terhadap Kinerja Guru di SMA Negeri 6 Binjai Kecamatan Binjai Utara (asumsi faktor lain konstan).

\subsection{Hipotesis}

\subsubsection{Pengujian Hipotesis Secara Simultan Menggunakan Uji - F}

Pengujian hipotesis secara simultan diperlukan untuk mengetahui apakah variabel $\mathrm{X} 1, \mathrm{X} 2$ dan X3 secara bersama-sama berpengaruh terhadap variabel $(\mathrm{Y})$. 
Tabel 4. Hasil Uji Serempak

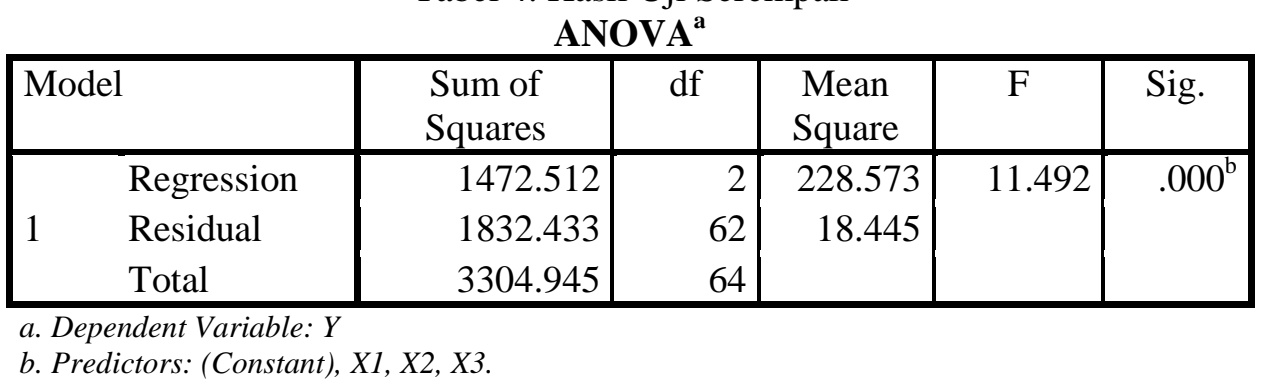

Pengujian hipotesis dilakukan dengan cara membandingkan besarnya angka $\mathrm{F}$ penelitian dengan $\mathrm{F}$ tabel, dengan kriteria sebagai berikut:

Jika $\mathrm{F}_{\text {hitung }}>\mathrm{F}_{\text {tabel }}$, maka $\mathrm{H}_{0}$ ditolak dan $\mathrm{Ha}$ diterima

Jika $\mathrm{F}_{\text {hitung }}<\mathrm{F}_{\text {tabel}}$, maka $\mathrm{H}_{0}$ diterima dan $\mathrm{Ha}$ ditolak

Berdasarkan tabel 5.16, angka $\mathrm{F}$ penelitian yang diperoleh dari hasil perhitungan adalah sebesar 11.492 Sedangkan angka $F$ tabel dihitung dengan taraf signifikansi 95\% dan alpha 5\% serta derajat kebebasan $(\mathrm{dk})$ dengan ketentuan $\mathrm{dk}=\mathrm{n}-2$ atau 64-2 $=62$, maka diperoleh angka Ftabel $=$ 2,75 .
Dengan demikian nilai $\mathrm{F}_{\text {hitung }}=11.492>\mathrm{F}_{\text {tabel }}$ $=2,75$, dengan nilai signifikansi $0,000<0,05$. karena $\mathrm{F}_{\text {hitung }}>\mathrm{F}_{\text {tabel }}$ yang berarti bahwa $\mathrm{H}_{0}$ ditolak dan Ha diterima, sehingga dapat disimpulkan bahwa Kecerdasan Emosional, Motivasi dan Komitmen berpengaruh positif dan signifikan terhadap Kinerja Guru di SMA Negeri 6 Binjai Kecamatan Binjai Utara.

\subsubsection{Pengujian Hipotesis Secara Parsial Menggunakan Uji t}

Untuk melihat besarnya pengaruh antara Kecerdasan Emosional, Motivasi dan Komitmen terhadap Kinerja Guru dan tingkat signifikansi secara parsial, digunakan uji t sebagai berikut :

Tabel 5. Hasil Uji Parsial

\begin{tabular}{|c|c|c|c|c|c|}
\hline \multirow[t]{2}{*}{ Model } & \multicolumn{2}{|c|}{$\begin{array}{c}\text { Unstandardized } \\
\text { Coefficients }\end{array}$} & $\begin{array}{l}\text { Standardized } \\
\text { Coefficients }\end{array}$ & \multirow[t]{2}{*}{$\mathrm{t}$} & \multirow[t]{2}{*}{ Sig. } \\
\hline & $\mathrm{B}$ & Std. Error & Beta & & \\
\hline \multirow{4}{*}{$\begin{array}{l}\text { Kec.Emosior } \\
\text { Iklim Kerja } \\
\text { Kompetensi }\end{array}$} & 8.772 & 0.525 & & 7.425 & .000 \\
\hline & .581 & .103 & .282 & 2.632 & .000 \\
\hline & .542 & .224 & .362 & 2.812 & .001 \\
\hline & .567 & .210 & .371 & 2.701 & .001 \\
\hline
\end{tabular}

a. Pengujian pengaruh variabel Kecerdasan Emosional $\left(\mathbf{X}_{1}\right)$ terhadap Kinerja Guru $(\mathbf{Y})$

Secara parsial uji statistik yang digunakan adalah uji t. hasil perhitungan SPSS berdasarkan tabel Coefficients, diperoleh nilai t hitung 2,632 dan t tabel 2,00, ini berarti bahwa nilai t hitung > nilai $t$ tabel $(2,632>2,00)$, dengan nilai signifikansi $0,000<0,05$ maka H01 ditolak dan Ha1 diterima. Hal ini berarti hipotesis diterima yaitu Kecerdasan Emosional berpengaruh positif dan signifikan terhadap Kinerja Guru di SMA Negeri 6 Binjai Kecamatan Binjai Utara.

\section{b. Pengujian pengaruh variabel Iklim Kerja} (X2) terhadap Kinerja Guru (Y)

Secara parsial uji statistik yang digunakan adalah uji t. hasil perhitungan SPSS berdasarkan tabel Coefficients, diperoleh nilai t hitung sebesar 2,812 dan $t$ tabel 2,00, ini berarti bahwa nilai $t$ hitung > nilai t tabel $(2,812>2,00)$, dengan nilai signifikansi $0,001<0,05$ maka H01 ditolak dan Ha1 diterima. Hal ini berarti hipotesis diterima yaitu Iklim Kerja berpengaruh positif dan signifikan terhadap Kinerja Guru di SMA Negeri 6 Binjai Kecamatan Binjai Utara.

\section{c. Pengujian pengaruh variabel Kompetensi} (X3) terhadap Kinerja Guru (Y)

Secara parsial uji statistik yang digunakan adalah uji t. hasil perhitungan SPSS berdasarkan tabel Coefficients, diperoleh nilai t hitung sebesar 2,701 dan $\mathrm{t}$ tabel 2,00, ini berarti bahwa nilai $\mathrm{t}$ hitung $>$ nilai t tabel $(2,701>2,00)$, dengan nilai signifikansi $0,001<0,05$ maka H01 ditolak dan Ha1 diterima. Hal ini berarti hipotesis diterima yaitu Komitmen berpengaruh positif dan signifikan terhadap Kinerja Guru di SMA Negeri 6 Binjai Kecamatan Binjai Utara. 


\subsubsection{Uji Determinasi $\left(\mathbf{R}^{2}\right)$}

Uji Determinasi dilakukan untuk mengetahui berapa besar pengaruh atau kontribusi variabel bebas terhadap variabel terikat yaitu Kecerdasan
Emosional (X1), Iklim Kerja (X2) dan Kompetensi secara bersama-sama terhadap Kinerja Guru (Y). Pengujian ini menggunakan nilai Koefisien determinasi atau $R$ square $\left(R^{2}\right)$.

Tabel 6. Koefisien Determinasi

Model Summary ${ }^{\text {b }}$

\begin{tabular}{|c|c|c|c|c|c|}
\hline Model & $\mathrm{R}$ & R Square & $\begin{array}{l}\text { Adjusted R } \\
\text { Square } \\
\end{array}$ & $\begin{array}{l}\text { Std. Error of } \\
\text { the Estimate }\end{array}$ & $\begin{array}{l}\text { Durbin- } \\
\text { Watson } \\
\end{array}$ \\
\hline 1 & $.791^{\mathrm{a}}$ & .625 & .561 & 3.2541 & 2.730 \\
\hline
\end{tabular}

Berdasarkan tabel diatas di dapat nilai $\mathrm{R}$ Square sebesar 0.625 atau $62,50 \%$. Maka dapat dijelaskan bahwa variabel Kecerdasan Emosional (X1), Iklim Kerja (X2) dan Kompetensi (X3) berpengaruh sebesar 62,50\% terhadap Variabel Kinerja Guru di SMA Negeri 6 Binjai Kecamatan Binjai Utara, sisanya sebesar 37,50 \% lagi dipengaruhi oleh Variabel lain yang tidak diikutkan dalam penelitian.

\section{Kesimpulan}

Dari pembahasan hasil penelitian diatas, maka dapat diambil beberapa kesimpulan dan saran sebagai berikut :

a. Variabel Kecerdasan Emosional berpengaruh positif dan signifikan terhadap Kinerja Guru di SMA Negeri 6 Binjai Kecamatan Binjai Utara, dengan nilai $\mathrm{t}$ hitung $>$ nilai $\mathrm{t}$ tabel ( $2,632>2,00$ ) dan pengaruhnya sebesar 0,581 atau $58,10 \%$.

b. Variabel Iklim Kerja berpengaruh positif dan signifikan terhadap Kinerja Guru di SMA Negeri 6 Binjai Kecamatan Binjai Utara, dengan nilai $\mathrm{t}$ hitung > nilai $\mathrm{t}$ tabel $(2,812>$ 2,00 ) dan pengaruhnya sebesar 0,542 atau $54,20 \%$.

c. Variabel Kompetensi berpengaruh positif dan signifikan terhadap Kinerja Guru di SMA Negeri 6 Binjai Kecamatan Binjai Utara, dengan nilai $\quad t$ hitung $>$ nilai $t$ tabel $2,701>2,00$ ) dan pengaruhnya sebesar 0,567 atau $56,70 \%$.

d. Variabel Kecerdasan Emosional, Iklim Kerja dan Kompetensi berpengaruh positif dan signifikan terhadap Kinerja Guru di SMA Negeri 6 Binjai Kecamatan Binjai Utara, dengan nilai $\mathrm{F}$ hitung > nilai $\mathrm{F}$ tabel $(11,492$ $>2,75$ ) dan pengaruhnya sebesar 0,625 atau $62,50 \%$.

\section{DAFTAR PUSTAKA}

Arikunto, S. 2002. Dasar-dasar Evaluasi Pendidikan. Jakarta: Bumi Aksara
2006. Prosedur Penelitian Suatu

Pendekatan Praktik. Jakarta: Rineka Cipta.

Aminah, Mimin, (2012) "Kecerdasan Emosional Membentuk Karakter Peserta Didik".,

Anonim. "Kecerdasan Emosional Pengertian, Definisi, dan Unsur-unsurnya". Dunia Psikologi

Anonim, (2012)“Pengertian Kecerdasan Emosional Menurut Para Ahli Faktor".

Anonim, (2013) "Pentingnya Kecerdasan Emosional".

Djamarah, Syaiful Bahri dan Aswan Zain. 2010. Strategi Belajar Mengajar. Jakarta: Rineka Cipta

Goleman, Daniel, (2001). Kecerdasan Emosional. Terj. T. Hermaya. Jakarta: Gramedia Pustaka Utama.

Gottman, John \& Joan de Claire, (2001). Kiatkiat Membesarkan Anak yang Memiliki Kecerdasan Emosional. Terj. T. Harmaya. Jakarta: Gramedia.

Hendry, (2010) "Definisi Kecerdasan Emosional (EQ)".

Poerwadarminto, Wjs.,Kamus Umum Bahasa Indonesia. Jakarta: Pusat Pembinaan dan Pengembangan Bahasa, Departemen Pendidikan dan Kebudayaan, 1995.

Rachmawati, Tutik dan Daryanto. 2013. Penilaian Kinerja Profesi Guru dan Angka Kreditnya.Yogyakarta. Gava Media

Rohani, Ahmad .(2005). Pengelolaan Pengajaran Jakarta : Rineka Cipta.

Soetopo, Hendrat, Administrasi Pendidikan, Malang: IKIP Malang, 2005

Saondi, Ondi dan Suherman Aris. 2010. Etika Profesi Keguruan. Bandung : PT Refika Aditama

Sanjaya, Wina. 2005. Strategi Pembelajaran. Jakarta : Kencana.

Silvana Illy. 2009. Pengaruh Kompetensi Profesional dan Produktivitas Guru terhadap Prestasi Belajar Siswa Program Keahlian 
Akuntansi SMK di Kota Semarang. Skripsi. Semarang: UNNES

Susanto, Ahmad 2013. Teori Belajar dan Pembelajaran di Sekolah Dasar, Jakarta: Kencana Prenadamedia Group

Slameto. 2003. Belajar dan Faktor-faktor yang Mempengaruhinya. Jakarta: Rinneka Cipta.

Sudjana, Nana. 2005. Dasar-Dasar Proses Belajar Mengajar. Bandung: Sinar Baru Algensindo

Sugihartono, dkk. (2007). Psikologi Pendidikan. Yogyakarta: UNY Press.

Thoha, 2010, Perilaku Organisasi, Raja Grafindo Persada, Jakarta

Usman, M.U. 2003. Menjadi Guru Profesional. Bandung: Remaja Rosdakarya. Undangundang Republik Indonesia Nomor 14 tahun 2005 Tentang Guru dan Dosen . Surabaya : Kesindo Utama

Winkel.(2005). Psikologi Pengajaran. Yogyakarta: Media Abad

Widjaya, Cece. 1991. Kemampuan Dasar Guru dalam Proses Belajar Mengajar. Bandung: Rosda Karya. 